Evaluasi: Jurnal manajemen Pendidikan Islam

ISSN (P): 2580-3387, ISSN (E): 2615-2886

DOI : http://doi.org/10.32478/evaluasi.v5i2.754

Article Type : Original Research Article

\title{
OTORITAS KEPEMIMPINAN KARISMATIK TUAN GURU DALAM MEMBENTUK BUDAYA RELIGIUS
}

\author{
Safinah', Zainal Arifin ${ }^{2}$ \\ ${ }^{1}$ IAI Hamzanwadi NW Lombok Timur, Indonesia \\ 2 UIN Sunan Kalijaga Yogyakarta, Indonesia
}

Corresponding author: safinah01almubarrok@gmail.com

Submission Track:

Submisson $\quad: 25-07-2021$

Accept Submission : 07-09-2021

Avaliable Online : :11-09-2021

Copyright @ 2021 Author

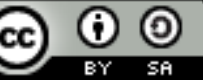

This work is licensed under a Creative Commons Attribution-ShareAlike 4.0

\begin{abstract}
This study describes the charismatic authority of TGH Syahri Ramadhan in shaping religious culture in the Darul Musthofa Nahdlatul Wathan Islamic boarding school, West Lombok. The data collection was carried out by: (1) observing a series of activities of santri in Islamic boarding schools to observe the daily religious culture and (2) in-depth interviews with asatidz, community leaders, and heads of foundations to explore the authority of TGH Syahri Ramadhan's charismatic leadership. The results show: First, the source of TGH Syahri Ramadhan's charismatic authority is the authority and karomah born of wirid practice and supported by the Islamic education tradition of Nahdlatun Wathann (NW) which has the jargon "sami'na wa atho'na" which means "we hear and we are obey" which is embedded in all residents of Islamic boarding schools. Second, TGH Syahri Ramadhan's charismatic leadership strategy in shaping a religious culture through : (1) planting the ideology of Ahlusunnah Waljamaah (Aswaja) based on the Imam ash-Syafi'l school of thought, (2) habituation of religious culture such as : (a) daily routine activities, (b) require all religious activities, (c) create a religious environment, (d) involve all school members. (3) the arrangement of symbols in the form of artistic attributes and art activities.
\end{abstract}


Keywords: Leadership Authority, Charismatic, Tuan Guru, Religious culture.

\begin{abstract}
Abstrak
Penelitian ini mendeskripsikan tentang otoritas karismatik TGH Syahri Ramadhan dalam membentuk budaya religius di pondok pesantren Darul Musthofa Nahdlatul Wathan Lombok Barat. Pengumpulan data dilakukan dengan: (1) observasi rangkaian kegiatan santri di pondok pesantren untuk mengamati budaya religius sehari-hari dan (2) wawancara mendalam kepada para asatidz, tokoh masyarakat dan ketua yayasan untuk menggali otoritas kepemimpinan karismatik TGH Syahri Ramadhan. Hasil penelitian menunjukkan: Pertama, sumber otoritas karismatik TGH Syahri Ramadhan adalah kewibawaan dan karomah yang lahir dari amalan wirid serta didukung dengan tradisi pendidikan Islam Nahdlatun Wathann (NW) yang memiliki jargon"sami'na wa atho'na" artinya "kami mendengar dan kami taat" yang tertanam pada seluruh warga pondok pesantren. Kedua, strategi kepemimpinan karismatik TGH Syahri Ramadhan dalam membetuk budaya religius melalui: (1) penanaman ideologi Ahlusunnah Waljamaah (Aswaja) bermazab Imam asy-Syafi'l, (2) pembiasaan budaya religius seperti: (a) kegiatan rutin harian, (b) mewajibkan seluruh kegiatan keagamaan, (c) menciptakan lingkungan religius, (d) melibatkan seluruh warga sekolah. (3) tatanan simbol dalam bentuk atribut dan aktivifitas seni.
\end{abstract}

Kata kunci: Otoritas Kepemimpinan, Karismatik, Tuan Guru, Budaya religius.

\title{
A. PENDAhuluan
}

Kiai memiliki peran penting bagi kemajuan pesantren dan merupakan tokoh utama dalam kelestarian tradisi pesantren. Karel A. Steenbrink dikutip oleh Samsul Nizar menjelaskan peran kiai sebagai unsur esensial pesantren yang memiliki pengetahuan agama luas, kesalehan, dan kepribadian terpuji. Kiai biasanya pendiri sekaligus pemilik pesantren yang hidupnya digunakan untuk agama dan masyarakat(Nizar, 2013, p. 115). Kiai memiliki daya tarik, wibawa, dan pengaruh yang lahir dari kedalaman ilmunya. Akhlak mulia serta ketaatan kiai dalam mengamalkan agama menjaditeladanbagi guru (ustadz), santri, dan masyarakat sekitarnya (Nizar, 2013). Di Jawa, pesantren diibaratkan sebagai sebagai kerajaan kecil di mana kiai merupakan sumber mutlak dari kekuasaan dan kewenangan dalam kehidupan dan lingkungan pesantren (Dhofier, 2011, pp. 93-94).

Kiai adalah sosok pemimpin karismatik. Pemimpin karismatik adalah orang yang mampu menaruh kepercayaan terhadap kebenaran dan keyakinan (Ramayulis \& Mulyadi, 2017). Bagimasyarakat Lombok, sosok pemuka agama yang karismatik biasanya disebut dengan Tuan Guru. Secara umum, Tuan Guru memiliki kriteria: (1) pengetahuan keagamaan, kesalehan, keturunan, jumlah murid, ahli membaca kitab kuning, (Fahrurrozi, 2010). Menurut Fahrurrozi, kalangan masyarakat memandang Tuan Guru adalah gelar istimewa yang diberikan kepada seseorang yang disegani karena ilmunya, kiprahnya dalam masyarakat, dan memiliki karisma(Fahrurrozi, 
2010:19). Agus juga menjelaskan bahwa Tuan Guru sebagai tokoh sentral dan public figure di masyarakat Sasak (Putrawan, 2014, p. 320).

Menurut Mohammad Iwan Fitriani, pembenaran prinsip tentang Tuan Guru adalah pengakuan masyarakat yang bergantung pada keilmuan dan prilaku religius (Fitriani, 2016, p. 178). Masyarakat Sasak menganggap Tuan Guru sebagai bentuk geneologi para penuntut ilmu yang berasal asli dari orang Lombok yang berkelana ke tanah suci Makkah sebagai santri dan melaksankan haji. Setelah mereka pulang ke lombok, kemudian mengajarkan masyarakat berbagai macam ilmu Agama dengan mendirikan majlis pengajian. Hal tersebut yang menjadi dasar diberikannya gelar Tuan Guru (TG). Setiap Tuan Guru yang pernah melaksnakan Haji, maka sebutan yang pantas adalah Tuan Guru Haji (TGH) atau isitilah lainnya adalah Tuan guru Kiai Haji (TGKH). Pada awalnya kebutuhan akan gelar Tuan Guru sangat ketat, namun sekarang agak ringan karena banyaknya orang yang pernah melaksnakan ibadah Haji kemudan setelah pulang membangun pondok pesantren serta membuat majlis ta'lim untuk masyarakat, mereka juga dikateogrikan Tuan Guru oleh beberapa sebagian masyarakat, walaupun pada dasarnya belum pernah menjadi santri di daerah Timut Tengah (Fitriani, 2016, p. 179).

Menurut Fahrurrozi yang dikutip oleh Agus mengemukakan bahwa ada lima kriteria umum seseorang bisa disebut Tuan Guru; (1) pengetahuan agama yang luas (2) ketaatannya kepada Allah SWT, (3) faktor genetik, (4) kuantitas muridnya, (5) fasih dalam membaca kitab turats (kitab kuning) dan memahami maknanya (Putrawan, 2014, p. 288). Sedangkan menurut TGH. Selain itu menurut Salimul Jihad dalam bukunya Samsul Anwar yang dikutip oleh Agus mengemukakan bahwa sayarat menjadi Tuan Guru adalah : (1) paham seluruh elemen ilmu keislaman baik secara lahirian maupun bathiniah, (2) merupakan alumni dari timur tengah, (3) pernah melaksanakan ibadah Haji di tanah suci Makkah, (4) bersikap dan berprilaku baik pada masyarakat, (5) bersosial dan menjalin intraksi dengan masyakarat, dan (6) memeiliki keistimewaan tertentu dalam pribadinya(Putrawan, 2014, pp. 288-289).

Kriteria untuk mendapatkan gelar 'Tuan Guru' sama halnya dengan gelar 'Kiai' bagi orang Jawa. Steenbrink mengungkapkan beberapa kriteria menjadi seorang 'Kiai', yaitu: (1) masyarakat mengakui sebagai kiai, (2) orang lain berdatangan untuk minta nasihat dan tausiyah (3) orang-orang mempercayainya keilmuannya dan mengantarkan anak-anak mereka untuk menjadi santrinya (Steenbrink, 1986). Selanjutnya menurut Steenbrink yang kutip dari Aboe Bakar Atjeh, mengungkapkan sebab seorang menjadi kiai besar, yaitu: ilmu agama yang luas dan mendalam, ketaatannya kepada Allah SWT, keturunan dari keluarganya, dan kuantitas murid yang banyak (Steenbrink, 1986). Abdurrahmah Wahid yang dikutip oleh Dawam Rahardjo mengungakapkan bahwa sumber inspirasi dan penguatan karakter serta moral santri adalah Kiai, sebab Kiai memiliki otoritas absolut atas kekuasaanya (Raharjo (ed), 1995:42-43). Kombinasi pendidikan ilmu keislaman dengan warisan karisma dari orang tua atau kiai lainnya merupakan sumber kekuasaan Kiai tersebut. (Rohmaniyah \& Woodward, 2012, p. 123) atau dalam istilah disebut sebagai kepemimpinan karismatik (Sukamto, 1999, p. 23). 
Bagi masyarakat Lombok, Tuan Guru juga kadang sebagai pendiridan pemilik pesantren yang karismatik, sebagaimana Kiai di Jawa.Perbedaannya, umumnya Kiai di Jawa adalah pemimpin pesantren yang berafiliasi dengan organisasi Nahdhatul Ulama (NU), sedangkan Tuan Guru di Lombok berafiliasi dengan organisasi Nahdhatul Wathan (NW). Fokus penelitian ini pada kajian sumber otoritas karismatik TGH syahri Ramadhan dan strateginya dalam pembudayaan perilaku religius santridi Pondok Pesantren (PP) Darul Musthofa Nahdlatul Wathan Lombok.

Pondok Pesantren Darul Mushtofa didirikan oleh TGH. Syahri Ramadhan,tokoh masyarakat Lombok yang pandai, cakap dalam ilmu agama (alim), dan karismatik.Sistem pendidikan di PP Darul Mushtofa adalah Khalafiyah (semi modern) yang menggabung kansistem Salafiyah (tradisional) dengan mengkaji kitab-kitab kuning (klasik) dan sistem modern dengan mendirin kanmadrasah formal tingkat Tsanawiyah (MTs) dan Aliyah (MA). Pondok pesantren ini berafiliasi dengan (NW) Nahdlatul Wathan (Thohri, dkk, 2016, p. 167).

Salah satutujuan pendidikan pesantren adalah membentuk santri yang religius. Pembudayaan perilaku religius di pesantren didukung oleh budaya religius yang ditanamkan dalam kehidupan pesantren. Menurut C. Chotimah dan M. Fathurrahman, nampaknya nilai keagamaan sebagai kebiasaan dalam berprilaku dan bersikap kemudian diikuti oleh seluruh warga pesantren adalah cerminan terbentuknya budaya religius (Chotimah \& Fathurrahman, 2014). Penanaman budaya religius yang tidak didukung oleh lingkungan berdampak pada perilaku santri.Sebagaimana dialami di PP. Darul Musthofa pada tahun 2010-2013, di mana para santri yang tinggal di rumahrumah masyarakat dusun Repok Atas cenderung sulit dikontrol dan santri bebas keluar masuk pesantren tanpa izin.

\section{B. METODE}

Metode penelitianmenggunakan pendekatan kualitatif untuk melihat obyek secara alamiah (Sugiyono, 2008), yaitu mengkaji sumber otoritas kepemimpinan karismatik TGH Syahri Ramadhan dalam membentuk budaya religius santri PP Darul Musthofa Nadhatul Wathan (NW). Adapun pengumpulan data menggunakan teknik observasi, wawancara mendalam, dan dokumentasi (Sugiyono, 2008). Observasi dilakukan untuk mengamati kegiatan para santri di pondok pesantren Darul Musthofa NW. Dalam penelitian ini, peneliti telah mewancarai Taufan Jayadi selaku ketua Yayasan, H. Turmudzi selaku tokoh masyarakat, dan para guru seperti ustaz Ilham Jayadi, Ustaz Taufiq Hidayat dan Ustaz Sarianto, untuk mendalami bagaimana sumber otoritas kepemimpinan karismatik TGH Syahri Ramadhan, serta strateginya dalam meningkatkan budaya religius di PP. Darul Musthofa NW. Sedangkan dokumentasi yang menjadi tambahan rujukan seperti buku do'a/wirid, kitab-kitab turats dan dokumen dari pondok pesantren seperti profil pondok pesantren Darul Musthofa.

Teknik analisis data dilakukan dengan cara mereduksi data lapangan, memilih data yang berkaitan dengan tema penelitian kemudian disajikandalam bentuk deskriptif, dan mengecek bahwa semua data didapatkan langsung dari lokasi penelitian dan beberapa informan penelitian seperti ketua yayasan, guru, dan 
masyarakat sekitar. Analisis data dalam penelitian kualitatif dimulai dengan menyiapkan dan mengorganisasikan data hasil observasi, wawancara dan dokumentasi dengan memilih dan menulis dalam bentuk transkip yang kemudian di saring sebagai bahan pembahasan dan memberikan kode dari hasil pengumpulan data tersebut sesuai dengan pokok pembahasan dan sub pembahasan dalam penelitian ini. Selanjutnya dari semua perolehan data tersebut di sajikan dalam bentuk pembahasan dengan integrasi teori dan fakta. Senada dengan analisis data menurut (Creswell et al., 2015) menjelasakan bahwa analsisi data dalam penelitian kualitatif dimulai dengan menyiapakan data, seperti transkip dan foto sebagai bahan analisis, kemudian mereduksi data tersebut menjadi tema melalui proses pengodean dan peringkasan kode, dan terakhir menyajikan data dalam bentuk bagan, tabel, atau pembahasan.

\section{HASIL DAN PEMBAHASAN}

\section{TGH Syahri Ramadhan: Pemimpin Karismatik}

TGH Syahri Ramadhan adalah sosok yang alim, saleh, berilmu agama tinggi, berwibawa, sopan dan santun. Karakter inilah yang membuatnya TGH Syahri Ramadhan dihormati, dihargai, dan diteladanioleh para santri dan masyarakatsekitarnya.Keteladanan (qudwah) dalam Kamus Besar Bahasa Indonesia(KBBI) berarti sesuatu yang patut ditiru atau dicontoh seperti perbuatan, kelakuan dan sifat (Hermino, 2014). Kepemimpinan TGH Syahri Ramadhan mencontoh empat karakter utama Nabi Muhammad saw., yaitu: shiddiq , amanah, tabligh, dan fathonah dalam arti mampu bersifat jujur, bertanggung jawab, dapat menyampaikan kebaikan, dan menjadi sosok yang cerdas dan bijaksana (Nugroho, 2016:13). Seorang pemimpin harus mampu memberi contoh dan teladan bagi pengikutnya (Usman, 2008). Berdasarkan wawancara TGH Syahri Ramadhan mengungkapkan bahwa keteladanan seorang pemimpin di Pondok Pesantren dibuktikan dengan banyaknya hadir di pondok, mengajar, bergaul dengan guru (ustadz) dan santri. Karena, pondok itu intinya pada pembinaan. TGH Syahri Ramadhan mengibaratkan bahwa pemimpin atau pembina atau pengasuh pondok pesantren itu seperti Ayam yang menetaskan telur di sarangnnya, kalau Ayam meninggalkan telurnya maka tidak akan bisa menetas".

Nilai-nilai karismatik TGH Syahri Ramadhan lahir karena posisinya sebagai pemimpin sekaligus pemilik pesantren yang memiliki pengaruh kuat di tengah masyarakat. Hasil wawancara dengan Ustaz Taufiq Hidayat menyebut TGH Syahri adalah sosok penyayang dan sikapnya yang hangat membuat semua warga pondok pesantren merasa terlindungi dan merasa aman berada dilingkungan pondok pesantren. Selain itu Ustaz Sarlianto juga mengungkapan bahwa TGH Syahri Ramadhan merupakan sosok karismatik yang mengutamakan syariat agama, kedisplinan dalam belajar dan mendidik akhlak yang mulia.

Dari pernyataan ini, karismatik TGH Syahri Ramadhan muncul dari kepribadian dan wibawa yang dimilikinya untuk mempengaruhi para pengikutnya. Menurut Ramayulis, seorang pemimpin karismatik menggunakan kewibawaan pribadinya (personal power) untuk mempengaruhi pengikutnya (Ramayulis \& 
Mulyadi, 2017). Pemimpin karismatik memiliki kekuatan, pesona, dan karisma yang luar biasa dalam mepengaruhi pengikutnya, sehingga memilikibanyakpengawal yang bisa di percaya(Kartono, 2001).Pemimpin karismatik juga di anggap mempunyai kekuatan gaib (supra natural power) dan kemampuan superhuman yang diperolah dari karunia Yang Maha Kuasa (Tuhan). Pemimpin karismatik juga inspiratif, berani, dan percaya diri (Hidayat \& Machali, 2012).Menurut Max weber, yang dikutip oleh Alfan Alfian bahwa ada tiga ciri pemimpin karismatik, yaitu: (1) memiliki kepekaan emosi yang tinggi, (2) mampu mempengaruhi yang lain secara luar biasa, dan (3) tidak mudah dipengaruhi oleh orang lain(Alfian, 2009).

Karisma TGH Syahri Ramadhan menjadikan beliau sebagai figur yang dikagumi, disanjung, disegani, dihormati dan menjadi panutan bagi santri dan masyarakat. Pengetahuan ilmu agama yang luas, keluhuran moral, dan karomahmerupakan sumber karisma TGH Syahri Ramadhan. Berdasarakan hasil wawancara dengan beberapa usatz di PP Darul Musthafa mengungkan bahwa bentuk karisma beliau yang sering ditemukan oleh warga pondok pesantren adalah ketika beliau berbicara semua mendengarkan dan mentaati, Disaat beliau menetapkan aturan semua diterima dengan lapang dada dan tidak berani melanggar. Selanjutnya Usatz Ilham Hadi mengungkapkan sosok TGH Syahri Ramadahan sangat segani oleh guru-gurunya dan juga oleh ulama lain seperti Mudir Assoulatiyah yaitu syaikh Majid Said, Syaikh Musthofa, dan para habaib. Lebih lanjut Ustaz Miliadi menungkpankan bahwa TGH Syahri Ramadhan adalah ulama karismatik yang santun, memuliakan nilai-nilai agama Islam, waro', zuhud, dan menjadi figur bagi masyarakat desa.

Pernyataan diatas menujukkan sifat kepribadian TGH Syahri Ramadhansebagai sosok karismatik yang membuatnya disegani dan menjadi panutan masyarakat. Karisma Tuan Guru juga diperkuat oleh jargon organisasi Nahdlatul Wathan (NW)yang berbunyi: "sami'na wa atha'na", artinya "kami mendengar kami setia". Dalam organisasi NW, jargon ini menjadi tradisi kuat yang berakar dari pengamalan sufisme termanifestasi dalam bentuk ketaatan total kepada pimpinan dan mutlak untuk di ikuti.

\section{Sumber Otoritas Kepemimpinan Karismatik TGH Syahri Ramadhan}

Dalam profil yayasan PP Darul Musthofa dapat peneliti dijelaskan bahwa TGH Syahri Ramadhan selain sebagai sosok pemimpin karismatik juga pendiri sekaligus pemilik PP. Darul Musthofa. Pesantren ini berkembang menjadi semi modern dengan mendirikan madrasah-madrasah formal seperti MTs dan MA Darul Musthofa dan memiliki strukturorganisasi dalam bentuk yayasan. Selain ini, PP. Darul Musthofa juga berafiliasi dengan organisasi Islam Nadhlatul Wathan (NW) Lombok, berbedadengan pesantren-pesantren di Jawa lebihbanyak yang berafiliasi di Nahdhatul Ulama (NU) atau ormas Islam lainnya, seperti Muhammadiyah, Hidayatullah, Salafi, dan lain sebagainya. 
Kajian tentang kepemimpinan kiai sudah banyak dilakukan oleh penelitipeneliti sebelumnya, khususnya di pesantren Jawa. Misalnya, Zainal Arifin mencatat ada tiga otoritas kepemimpinan spiritual di Pondok Pesantren al-Fatah Temboro, yaitu tradisional, karismatik, dan rasional. Tiga otoritas ini bersumber pada tiga tradisi, yaitu: (1) pendidikan pesantren, (2) ideology Jamaah Tabligh, dan (3) tarekat Naqsyabandiyah-Khalidiyah. Kedua, otoritas karismatik bersumber pada kualitas spiritual kiai dan diperkuat dengan karomah. Ketiga, otoritas rasional bersumber pada usaha rasional kiai dalam membuka madrasah-madrasah formal sebagai bentuk modernisasi lembaga pendidikan Islam (Arifin, 2017).

Mastuhu menemukan beberapa pola kombinasi terhadap kepemimpinan kiai, yaitu: kepemimpinan karismatik, kepemimpinan otoriter-kebapakan, dan kepemimpinan laissez faire (Mastuhu, 1994:86). Sukamto menjelaskan bahwa masuknya pendidikan umum dari pola kemimpinan karismatik yang tunggal kea arah kepemimpinan kolektif merupakan penyebab terjadinya perubahan pola kepemimpinan Kia dan struktur kekuasaan di pondok pesantren. Kekuasaan kiai mengalami diferensiasi karena sistem pendidikan pesantren harus menyesuaikan diri dengan kurikulum pemerintah(Sukamto, 1999).Sedangkan Muhtarom dalam penelitiannya di pesantren tradisional menemukan pola kepemimpinan karismatik, otoriter-kebapakan dan demokratis. Gaya karismatik berkombinasi dengan model kepemimpinan paternalistik menuju demokrasi yang memiliki sikap sangat protektif terhadap ustadz dan santri tapi masih bersikap demokratis dan memberikan bimbingan kepada jajaran pengurus pondok pesantren dan para ustadz(Muhtarom H. M, 2005).

Artikel ini fokus mengkaji bagaimana otoritas kepemimpinan karismatik TGH. Syahri Ramadhan dan bagaimana strategi beliau dalam pembudayaan perilaku religious santri PP. Darul Mustofa. Kata 'karisma' dalam bahasa Yunani berarti karunia yang diinspirasi ilahi (divinely inspired gift) seperti kemampuan untuk melakukan mukjizat atau memprediksi peristiwa-peristiwa di masa depan (Yulk, 1998). Sedangkan Kepemimpinan karismatik menurut Weber (Thompson, 1977) dalam Sulaiman Kurdi (2007) bersumber pada pengaruh (emosional) yang bersifat individual pemimpin. Perubahan organisasi kepemimpinan karismatik bersifat dinamis (Kurdi, 2007), artinya tergantung pada karisma kiai. Weber (dalam Bryan S. Turner dan Abdul Ghafar Karim),bahwa gaya karismatik didominasi oleh kepatuhan (total) para pengikutnya, bukan karena aturan (legal) atau tradisi (Turner, 1974). Otoritas karismatik berdasarkan pada kepribadian individu pemimpin yang memiliki legitimasi berdasarkan pada kualitas spiritual pemimpin yang melahirkan keyakinan dan kepatuhan para pengikutnya (Karim, 2009).

Otoritas karismatik TGH. Syahri Ramadhan nampak dari wibawa beliau yang mampu mempengaruhi masyarakat dan warga pondok pesantren, sehingga timbul ketaatan dan kepatuhan masyarakat dan warga pondok pesantren tanpa ada keraguan sedikitpun. Sumber otoritas karismatik terletak pada kualitas individu kiai, yang tidak dimiliki atau sulit dimiliki oleh masyarakat, seperti kekuatan ibadah (spiritual), kelebihan-kelebihan, karomah, dan lain-lain(Arifin, 
2017).Karisma merupakan kualitas khusus yang dimiliki oleh seseorang yang berfungsi semacam magnet, pada dasarnya terdiri dari banyak sifat. Salah satu unsur yang paling penting adalah sifat kepercayaan diri(Danim, 2010).

Masyarakat mengakui kekaromahan TGH Syahri Ramadhan, sepetti hasil wawancara dengan $\mathrm{H}$. Turmudzi mengungkapan bahwa jamaah pengajian yang sangat banyak menunjukkan bahwa TGH Syahri Ramadhan adalah sosok panutan yang baik. Bentuk dari karisma beliau bukan hanya dari masyarakat dan warga pondok pesantren, akan tetapi dari sesama sebagai tuan guru, sama-sama orang alim, menyatakan hal yang sangat luar biasa, seperti yang di ungkapkan oleh TGH. Sulaiman dalam pengajian di PP. Darul Musthofa, beliau mengatakan "TGH. Syahri Ramadahan niki toa'an nie nu dait ite, laguk lamun umur jak toa'an ite" artinya "TGH Syahri itu lebih tua daripada kita semua (ini dari segi keilmuanny) tapi dari segi umur lebih tua saya. Ungkapan TGH Salaman tersebut menunjukkan bahwa tingkat keilmuan dan kealiman TGH Syahri Ramadhan diakui oleh Tuan Guru yang lain.

Artikulasi kepedulian dari Guru akan membawa makna yang luar biasa secara lokal, misalnya keluarnya seorang Tuan Guru di atas, yang mengatakan bahwa TGH Syahri Ramadhan adalah "guru kita". Akan muncul dalam kepribadian seorang bahwa arti penting dari artikulasi ini adalah pujian yang ditujukan kepadanya mengingat informasinya yang belum pernah ada sebelumnya. Hal ini akan menyebabkan individu menerima bahwa sosok TGH Syahri Ramadhan adalah pribadi yang patut diteladani, dihormati, dan dijadikan panutan dalam segala aspek kehidupan.

Sebagai pribadi yang menjadi figur dan panutan masyarakat, seyogyanya TGH Syahri Ramadhan memiliki sikap spiritualitas yang sempurna. Pengelolaan emosi, mampu mengendalikan hawa nafsu, dan orientasi kehidupan untuk akhirat semata merupakan indikator dari terbentuknya sikap spiritualitas pada individu dan spiritualitas islam dapat diperoleh dari tasawuf (Farhan \& Hadisaputra, 2020). Amalan tasawuf dalam organisasi NW adalah amalan wirid Hizib Nahdlatul Wathan dan Thariqat Hizib Nahdlatul Wathan. Keduanya merupakan karangan guru besar pendiri Nahdaltul Wathan yaitu Tuan Guru Kiai Haji (TGKH) Zainudin Abdul Majid. Berdasarkan hasil wawancara dengan TGH Syahri Ramadahan mengungkapkan bahwa amalan atau wirid yang sering diamalkan dilingkungan pondok pesantren Darul Muthofa dan juga masyarakat adalah membaca Hizib Nahdlatul wathan dan Tarekat Hizib Nahdlatul Wathan dengan tujuan agar terhindar dari keburukan, kejahatan dan gangguan penyakit zohir maupun bathin.

Kebersihan bathin akan mencerminkan sikap dan prilaku yang baik, dan akan menjadikan pelakunya menjadi berwibawa. Sehingga dalam hal ini peneliti menyimpulkan bahwa Wibawa TGH Syahri Ramadhan bersumber dari amalan tasawuf yaitu antara lain; Hizib Nahdlatul Wathan dan Thariqat Hizib Nahdlatul Wathan. Secara normatif doktrinal menunjukkan bahwa sumber wirid tersebut adalah ajaran tasawuf yang bertujuan untuk menjalin komunikasi transiden dengan sang kholiq. Manurut (Ziadi, 2018) hal tersebut merupakan manifestasi 
ajaran tasawuf dalam praksisnya yang meliputi sistem wirid, zikir, do'a, etika tawassul, dan ziarah sebagai jalan sufi.

Selain wirid, karismatik TGH Syahri Ramadhan di kuatkan dengan kultur keorganisasian yaitu "sami'na watho'na" yang artinya "kami mendengar kami taati" merupakan bentuk ajaran dalam Al-Qur'an yang termanifestasi dalam prilaku kepemimpinan. Kultur NW tersebut menjadi doktrin untuk masyarakat NW agar taat dan patuh pada pimpinan. Nasip (2019) Menyebutkan bahwa kultur "sami'na watho'na" merupakan karakter ketaatan seluruh warga NW kepada pemimpin dan sebagai penopang dalam menjalakan kewajiban keorganisasian (Nasip et al., 2019). Sehingga TGH Syahri Ramadhan sebagai pemimpin Pondok Pesantren sekaligus sebagai figur masyarakat, maka perbuatan dan ucapannya diikuti oleh seluruh pengikutnya.

\section{Pembentukan Budaya Religius}

Untuk menganalisis dimensi religius, peneliti menggunakan teori Glock dan stark dalam Robetson (1993) terdapat lima dimensi keberagamaan (religiusitas) yaitu: Pertama; Dimensi keyakinan (religious belief) merupakan pengharapan seorang terhadap pandangan teologis yang dianutnya, dan mengakui kebenaran doktrin dari teologi yang dianutnya. Kedua; Dimensi Praktik Agama (religious practice) merupakan bentuk pelaksanaan ritual-ritual keagamaan, ketaatan dalam menjalankan perintah agama, dan melakukannya secara continue sebagai komitmen terhadap agama. Ketiga; Dimensi pengalaman (religious feeling) yang berkaitan dengan pengalaman, perasaan, persepsi dan sensasi yang dialami sebagai individu yang beragama. Keempat; Dimensi pengetahuan agama (religious knowledge) pengetahuan mengenai dasar-dasar idiologis dalam bentuk ritus-ritus, kitab suci keagamaan, dan tradisi-tradisi keagamaan. Kelima; Dimensi konsekuensi (religious effect) merupakan bentuk identifikasi individu dari akibat-akibat keyakinan keagaman, praktek keagamaan, pengalaman keagamaan, dan pengetahuan keagamaan seseorang pada setiap harinya (Robertson, 1993).

a. Dimensi Keyakinan (religious belief)

Dimensi keyakinan terbentuk oleh idiologi pendidikan yang sudah ditetapkan di pondok pesantren Darul Musthofa yaitu ahlusunnah wal jamaah dan bermazhab kepada imam as-Syafi'i. Berdasarkan hasil wawancara dengan TGH Syahri Ramadahan mengungkapkan juga bahwa dalam proses pengayaan di pondok pesantren Darul Musthofa terselifkan juga dari mazhab-mazhab yang lain tapi dalam bentuk cerita dan perbandingan saja. Tidak dibahas secara mendalam karena dikhawatirkan akan membingungkan santri dengan berbagai macam khilafiah para imam mazhab

Idiologi ahlussunah waljamaah, dalam bidang aqidah atau keyakinan mempercayai keberadaan rukun iman, yaitu keyakinan pada Allah SWT, malaikat, kitab-kitab Allah, Nabi dan Rasul, datangnya hari ahir, dan keyakinan adanya qada dan qadar (ketentuan baik dan buruk). Term Iman, seperti yang 
kita ketahui adalah meyakini dengan hati, kemudian diucapakan dengan Lisan, dan direalisasikan dalam kehidupan dalam bentuk perbuatan. Begitu juga dengan rukun Islam yang lima, yaitu: mengucap dua kalimat syahadat, sholat, berpuasa, zakat, dan naik haji bagi yang mampu. Dengan rukun Iman yang enam merupakan dasar aqidah atau kepercayaan di lingkungan pondok pesantren Darul Musthofa, dengan dasar inilah kemudian direalisasikan dalam bentuk amal dan perbuatan yang dilakukan oleh seluruh warga pondok pesantren.

Selanjutnya penguatan keimanan di pondok pesantren Darul Musthofa yaitu, dengan mempelajari kitab As-Sa'adah, berdasarkan hasil dokumentasi dari teks kitab As-Sa'adah, dalam kitab ini membahas tentang Iman, Islam, Aqal, Sifat Wajib bagi Allah, Sifat mustahil bagi Allah, kerasulan Nabi Muhammad SAW, Tugas Rasul, Sifat Wajib bagi Rasul, Sifat Mustahil bagi Rasul, Jumlah Rasul, Kelahiran Nabi Muhammad SAW, Mu'jizat Nabi Muhammad SAW, sifat Sam'iyat, keyakinan Siratalmustaqim, Syafaat, Syurga, Neraka, Malaikat, Kitab-Kitab Allah, Qada dan Qadar.

b. Dimensi Praktik Agama (religious practice)

Praktik agama merupakan ibadah yang dikerjakan semata-mata karena pengabdian kepada Allah SWT yang menunjukkan bahwa orang tersebut patuh dan taat terhadap keyakinannya, yaitu dengan menjalankan perintah Allah dan menjauhi larangan-Nya. Praktik agama merupakan bentuk keataatan kepada Allah SWT yang sering disebut sebagai Ibadah. Melaksanakan ibadah merupakan manifestasi dari Taqwa.

Praktik agama di lingkungan pondok pesantren Darul Musthofa berdasarkan hasil wawancara dengan TGH Syari Ramadahan menyebutkan dua hal yang paling penting dalam praktik Agama yaitu; (1) ibadah wajib, yaitu: Shalat, Puasa, dan zakat. (2) ibadah sunnah, seperti; shalat sunnah, seperti; sholat duha berjamaah, sholat sunnah qobliyah dan ba'diyah, sholat sunnah witir, dan sholat sunnah tertentu seperti; sholat sunnah tasbih, sholat sunnah gerhana. Mengerjakan puasa sunnah seperti; puasa senin dan kamis, puasa sunnah hari asyura, puasa syawal, puasa sunnah Tasu'a, dan puasa sunnah arafah. Ibadah sebagai sarana untuk menumbuhkan kesadaran terhadap kewajiban individu dan sebagai bekal menuju keselamatan diakhirat kelak bagi umat yang beragama.

c. Dimensi Pengalaman (religious feeling)

Pengalaman beragama setiap individu tentunya berbeda-beda, tergantung kualitas masing-masing individu, namun dalam pengharapan dari praktik agama tujuannya hanya satu yaitu mengharapkan Ridho Allah SWT. Proses pelaksanaan ibadah di lingkungan PP Darul Musthofa berdasarkan hasil observasi menunjukkan bahwa pelaksanaan ibadah tersebut dilakukan dengan khusyuk dan tertib, seperti dalam kegiatan berdoa, semua santri membuka buku do'a, dan membaca doa secara serentak, tidak ada yang main-main, semua berdo'a dengan penuh ketundukan dan semata-mata mengharapkan 
semua do'a yang di baca dikabulkan oleh Allah SWT. Begitu juga ketika melaksankan ibadah sholat, semua santri bershaf dengan rapi dan lurus, kemudian membaca surah an-Nas sebelum mulai sholat, menjalankan sholat dengan khusyu' dengan harapan sholat yang dikerjakan diterima oleh Allah SWT.

\section{d. Dimensi Pengetahuan Agama (religious knowledge)}

Pengetahuan keagamaan untuk seluruh warga Pondok Pesantren Darul Musthofa diinternalisasikan dengan baik melalui kegiatan-kegiatab sekolah dan kepondokan. Sebagai sosok karismatik dan dengan pengetahuan keilmuan Agama yang memumpuni, TGH Syahri Ramadahan memberikan pengajaran Agama yang lebih banyak daripada pelajaran umum.

Pengetahuan keagamaan dalam komunitas pesantren Darul Musthofa tercermin dari idiologi keagamaan, yaitu Ahlussunah Waljamaah dan yang termanifestasi dalam bentuk pengetahuan Iman, pengetahuan Ibadah, pengetahuan Akhlak. Dengan pengetahuan keagamaan tersebut direalisasikan dalam bentuk prilaku yang tercermin dalam kehidupan sehari-hari.

e. Dimensi Konsekuensi (religous effect)

Implikasi dari keyakinan, praktik, pengalaman, dan pengetahuan keagamaan yang dialami oleh santri pondok pesantren Darul Musthofa, pertama: Dalam aspek keimanan semua santri meyakini keberadaan rukun iman dan rukun islam, bahkan berdasarkan hasil observasi menunjukkan semua santri menghafal dan mengamalkannya, seperti: (1) percaya kepada Allah SWT; menjalankan perintahnya dan menjauhi larangannya, seperti shalat, puasa, (2) Percaya pada malaikat; semua santri menghafal 10 malaikat yang wajib diketahui bersamaan dengan tugas-tugasnya, (3) percaya pada Kitab Allah; membaca (tadarus) al-Qur'an, belajar tata cara membaca al-Qur'an dengan metode Qiroati, belajar tafsir al-Qur'an dan juga belajar seni baca AlQur'an, (4) percaya pada Nabi dan Rasul; santri menghafal dan 25 Nabi dan Rasul, (5) percaya pada hari akhir (kiamat); santri terus berlomba-lomba menuju kebaikan, karena mereka tahu bahwa hidup di dunia hanyalah sementara, dan kehidupan yang kekal dan abadi yaitu di ahirat. (6) percaya pada Qada dan Qadar (ketentuan baik dan buruk); santri selalu berusaha untuk menjadi lebih baik, dengan terus belajar dan mengaji, walaupun dalam memahami pelajaran berbeda-beda ada yang lebih cepat paham dan ada juga yang lambat. Tapi mereka percaya bahwa bahwa semua itu adalah ketentuan yang telah di tetapkan oleh Allah SWT.

Kedua; Dalam aspek ibadah semua santri melaksanakan ibadah, baik itu ibadah mahdhah dan ghairu mahdhah. Santri menjalankan ibadah wajib seperti shalat dan puasa, begitu juga dengan perkara sunnah, seperti shalat sunnah; dhuha, tahajjud, tasbih, dan juga puasa sunnah; senin dan kamis, puasa hari arafah yaitu pada tanggal 9 Dzulhijjah, puasa asyura (10 muharrom), dan puasa syawal. Ketiga; Dalam aspek akhlak: (1) santri berprilaku sopan dan santun; saling menghargai antar sesama, menyanyangi yang lebih kecil dan 
menghormati yang lebih tua, selain itu juga berpakain yang menutup aurat dengan sempurna, seperti gamis, jubah, dan jilbab lebar (2) bertutur kata yang baik; mengunakan bahasa yang halus dan sopan, (3) hormat kepada guru; menjaga jarak dengan guru, apabila bersalaman mencium tangan guru dengan bolak balik, dan agak merunduk ketika di depan guru (4) saling memberi dan berbagi; kebiasaan santri di pondok saling berbagi makanan sesama temannya apalagi ada santri yang dijenguk oleh orang tuanya, (5) sabar; sabar dalam mengaji, sabar dalam menahan lapar, sabar dalam menjalani programprogram yang ada di pondok pesantren, dan (6) jujur; santri bersikap jujur atas perkara yang harus dipertanggung jawabkan

Dari lima dimensi religiusitas yang tercermin pada PP Darul Musthofa maka dapat peneliti klasifikasikan bentuk budaya religius menjadi 3 macam, yaitu:

a. Budaya religius di sekolah

PP. Darul Musthofa, selain memiliki asrama juga lembaga pendidikan formal (sekolah). Adapun budaya-budaya religius di sekolah berdasarkan hasil observasi seperti: (1) membaca doa/wirid Syawariqul Anwar karya As-sayyid Muhammad Alawi al-Maliki al-Hasani,(2) ngaji pagi, (3) sholat dhuha berjamaah, (4) tadarus al-Qur'an sebelum mulai belajar, dan (5) ihtiram, yaitu penghormatan kepada guru. Tadarus al-Qur'an dilaksanakan pada jam 7:30 setelah santri selesai berdoa (wirid) dan ngaji pagi, kemudian santri masuk kedalam kelas dan melanjutkan dengan tadarus al-Qur'an selama 10 menit, sebelum proses belajar mengajar berlangsung.

Berdasarkan hasil wawancara dengan ustaz Taufan Jayadi mengungkapkan bahwa Ihtiram merupakan bentuk kegiatan penghormatan santri kepada guru (ustadz) yang hendak mengajar di dalam kelas. Berdasarkan hasil observasi kegiatan Ihtiram dilakukan oleh santri ketika di kelas, majlis ta'lim, dan mudzakarah. Dalam peraktiknya dipimpin oleh seorang ketua dengan melantunkan ihtiram dengan suara lantang, kemudian semua yang berada dalam kelas atau majlis tersebut berdiri sampai guru atau ustaz tiba di tempat duduknya, lalu ketua melanjutkan dengan melantunkan "hayyu", seluruh peserta didik atau peserta majlis serentak mengucapkan salam; "Assalamualaikum warahmatullahi wabarakatuhu", kepada guru atau ustaz tersebut.

b. Budaya Religius di Asrama (Pondok)

Setiap pesantren memiliki budaya untuk meningkatkan perilaku religius santrinya. Berikut ini beberapa budaya religious di asrama PP. Darul Musthofa berdasarkan hasil wawancara dengan TGH Syahri Ramadhan, yaitu: (1) shalat Sunah tasbih yang dilakukan seminggu sekali pada malam Rabu setelah shalat Maghrib di Masjid Nurul Musthofa Repok Atas, (2) Peringatan Hari Besar Islam (PHBI) seperti Tahun baru Islam (1 Muharam), Maulid Nabi, Isra' Mi'raj, dan lain sebagainya, dan (3) puasa Sunnah Senin-Kamis.

c. Budaya Religius pada Masyarakat

Selain di sekolah dan pondok (asrama), TGH. Syahri Ramadhan juga punya peran dalam pembentukan budaya religius bagi masyarakat sekitar PP. Darul 
Musthofa. Berikut ini budaya-budaya religius yang berkembang di masyarakat Repok Atas, yaitu: Pertama, iringan hadrah Darul Musthofa saat upacara pernikahan, khitanan dan kurisan yang sebelumnya (tradisi lama masyakarat Lombok) menggunakan alunan musik tradisional gendang beleq" dan "kecimol".

Kedua, istighasah (doa bersama) untuk mendekatkan diri kepada Allah dan memohon pertolongan-Nya. Bentuk istighasah dengan cara hiziban jamaah muslimat Al-Baqiyatussolihah NW, zikiran dan doa bersama jamaah muslimin Assabiqunal Awwalun Dusun Repok Atas, doa bersama nisfu sya'ban, dan doa bersama pada awal tahun dan ahir tahun. Dalam kegiatan ini semua elemen mengikuti acara tersebut seperti masyarakat setempat, masyarakat umum, dan warga pondok pesantren.

\section{Strategi Pengembangan Budaya Religius di Pondok Pesantren Darul Musthofa}

Untuk mencapai budaya religius yang sempurna, perlu adanya optimalisasi kegiatan-kegiatan yang ada di lingkungan PP Darul Musthofa yaitu dengan membentuk strategi pengembangan budaya religius. Strategi pengembangan budaya religius dalam komunitas Madrasah dapat dilakukan melalui tiga tataran, yaitu: pertama; Tatanan nilai yang dianut. Kedu; Praktik keseharian. Ketiga; Simbol-simbol budaya (Muhaimin, 2011).

a. Tataran Nilai yang Dianut

Tataran Nilai yang dianut dipondok pesantren Darul Muthofa adalah sesuai dengan idiologi organisasi Nadhlatul Wathan yaitu ahlusunnah waljamaah ala mazhabil imam as-syafi'. Keberadaan idiologi ini disepakati oleh seluruh warga pondok pesantren sebagai dasar dalam proses menjalankan pendidikan di pondok pesantren. Seluruh warga pondok pesantren sepakat bahwa idiologi pendidikan yang terapkan di pondok pesantren yaitu sesuai dengan idiologi Nahdlatul Wathan. Keberadaan idiologi tersebut menjadi doktrin di lembaga pondok pesantren yang yang tidak bisa di interpensi oleh idiologi-idiologi yang lain. Sudah dijelaskankan juga oleh TGH. Syahri Ramadhan bahwa idiologi tersebut merupakan idiologi organisasi Nahdlatul Wathan yang kemudian beliau bawa ke lingkungan pondok pesantren Darul Musthofa.

b. Praktik Keseharian.

Dengan tataran nilai yang telah disepakati menjadi pondasi bagi warga pondok pesantren Darul Musthofa untuk mewujudkannya dalam bentuk sikap dan prilaku, seperti dalam tataran nilai aqidah atau keyakinan (keimanan), meyakini bahwa tiada Tuhan selain Allah SWT, dan Muhammad adalah utusan Allah SWT, yang kemudian termanifestasi bentuk sikap dan prilaku hidup sehari-hari dengan menjalankan perintah-Nya dan menjauhi larangannya. 
Praktik keseharian dapat peneliti rumuskan menjadi beberapa macam yang menjadi strategi pengembangan budaya religius (religious culture) di PP Darul Musthofa yaitu:

1) Melakukan kegiatan rutin setiap hari

Kegiatan yang mendukung terhadap perkembangan budaya religius beradasarkan hasil wawancara dengan para guru di pondok pesantren Darul Musthofa yaitu membaca Al-Qur'an di luar program yang telah ditetapkan, mudzakarah, shalat sunnah ba'diah dan qobliyah, wajib shalat berjamaah, shalat sunnah dhuha, dan tahajjud adalah merupakan kegiatan rutin yang mendukung perkembangan budaya religius di pondok pesanren Darul Musthofa. Selain pendidikan agama, pembentukan sikap, perilaku, dan pengalaman keagamaan merupakan indikator penting untuk di budayakan dalam bentuk kegiatan keseharian yaitu; (1) dengan membuat kelompok mudzakarah diluar jadwal formal yang telah ditetapkan; (2) berpakaian wajib menutup aurat, (3) sholat berjamaah, (4) melakukan kebersihan asrama.

Berdasarkan hasil observasi menunjukkan bahwa kegiatan rutin yang dilakukan di pondok pesantren terdiri dari tiga aspek yairu dari aspek ibadah, pendidikan, dan akhlak. Dengan kegiatan rutin ini terjadi proses internalisasi nilai-nilai agama, sehingga sangat berpengaruh terhadap keberlangsungan budaya religius yang ada di PP Darul Musthofa.

2) Menjadikan kegiatan keagamaan sebagai kegiatan yang wajib

Mewajibkan santri untuk ikut semua program yang ada di pondok pesantren, dan diberikan hukuman bagi yang tidak mengikutinya, berdasarkan hasil wawancara dengan ketua yayasan Ustaz Taufan Jayadi mengungkapkan kewajiban santri di pondok pesantren seperti; (1) mewajibkan para santri untuk mengikuti kegitan-kegiatan yang berkenaan dengan kewajiban kepada Allah SWT, seperti; shalat berjamaah, sholat Sunnah, dan zikir bersama, (2) santri diwajibkan berpakaian rapi, menutup aurat, serta membatasi pakaian para santri, (3) memisahksan santri putra dan putri pada kegiatan-kegiatan, baik kegiatan Asrama maupun kegitan Madrasah. (4) Memberikan sanksi-sanksi bagi santri yang melanggar aturan, yaitu dengan sanksi yang bernilai mendidik seperti baca al-Qur'an, shalat sunnah Mutlak, dan ada juga yang direndam didalam Kolam.

Program mewajibkan santri dalam melaksanakan kegiatan-kegiatan kepondokan merupakan upaya yang sangat efektif dalam membentuk, membina dan membiasakan santri dalam melaksnakan kegiatan keagamaan, setelah kebiasaan itu terbentuk maka santri akan menjadi disiplin dan taat dalam melaksanakan ibadah kepada Allah SWT. Dan bentuk punishment yang diberlakukan kepada santri yang melanggar perkara-perkara yang diwajibkan tersebut adalah punisment yang bernilai ibadah dan mendidik. 
Adapun sangsi-sangsi apabila santri melanggar program berdasarakan hasil dokumentasi dari papan sangsi pelanggaran tertulis : (1) sanksi ringan meliputi: teguran secara lisan dan tulisan, membaca AlQur'an 3 juz didepan guru, sholat sunnah taubat 100 rokaat, dan skorsing selama satu minggu, dan (2) sanksi berat meliputi: digundul, pemanggilan orang tua/wali, direndam dalam kolam, dan dikeluarkan dari sekolah.

3) Menciptakan lingkungan pondok pesantren yang religius

Lingkungan lembaga pendidikan, lingkungan keluarga dan lingkungan masyarakat sangat empengaruhi pertumbuhan dan perkembangan santri. Pondok pesantren mampu menanamkan nilai-nilai keagamaan yang lebih luas sehingga pondok pesantren mampu membentuk generasi-generasi yang bermutu dan berkarakter islami. Santri yang terbentuk dari pondok pesantren bisa menjadi pelaku-pelaku utama kehidupan di masyarakat. Suasana lingkungan yang kondusif dan mendukung terhadap penyampaian pendidikan agama yang tercermin dalam prilaku peserta didik dengan berakhlak yang mulia, prilaku jujur, disiplin dan semangat sehingga akhirnya menjadi dasar untuk meningkatkan kualitas dirinya.

Lingkungan yang religius membentuk santri yang religius. Bentuk lingkungan yang religius berdasarakan hasil observasi dapat dilihat dari; cara berpakaian santri sehari-hari menggunakan sarung dan berpeci, santri perempuan dianjurkan menggunakan purdah (cadar) keculai bagi yang tahfiz diwajibkan, apabila orang tua santri datang menjenguk anaknya ke Asrama maka harus menggunakan pakaian yang rapi dan wajib berhijab bagi perempuan. Seperti yang diungkapkan oleh Ustazd Ilham sebagai pembina asrama mengatakan bahwa Santri di wajibkan berpakaian rapi, menutup aurat serta membatasi pakaian bagi para santri.

4) Melibatkan Guru dan Pengurus Asrama

Dalam mengembangkan budaya religius, tidaklah cukup hanya santri yang berjalan dengan sendirinya tanpa ada pengawasan dari para guru atau ustazd, sehingga di pondok pesantren Darul Musthofa melibatkan semua guru, berdasarakn hasil wawancara dengan ketua yayasan ustaz Taufan Jayadi mengungkapkan bahwa sekalipun tidak terlibat setiap hari, yang paling penting dalam meninggkatkan budaya religius adalah keterlibatan seluruh guru, pembina, karena pembina menjadi qudwah disana.

Seluruh warga sekolah mempunyai tanggung jawab dalam mengembangkan budaya religius, seperti yang TGH Syahri Ramadhan sampaikan bahwa pembina asrama akan menjadi teladan bagi seluruh santri yang ada di asrama, jadi selain memberikan contoh yang baik, maka harus dibina, diawasi dan dikontrol segala tingkah laku para santri yang ada di Asrama yaitu dengan evaluasi mingguan bersama dewan guru dan pembina asrama untuk membahas kelemahan, hambatan, permasalahan 
yang terjadi setiap program yang dilaksanakan, khusunya yang bentuknya budaya religius dan berupaya agar tetap optimis, tekun, telaten, bersabar, ikhlas menjalaninya karena Allah SWT, serta Istiqomah.

Adapun upaya yang di lakukan oleh guru dalam keterlibatannya dalam mengawasi praktik budaya religius dengan melatih dan mendidiknya agar terbiasa hidup di lingkungan yang religius, membiasakannya berbicara dengan santun, tetap menyuruhnya untuk berpakain yang rapi dan berbusana muslim, tidak memberikan membawa hp ke pondok dan ke sekolah. Totalitas dari upaya yang dilakukan merupakan keterlibatan total pengurus, guru, dan pembina asrama dalam mengembangkan budaya religius, semua saling mendukung dan saling bekerjasama (teamwork) sehingga pelaksanaan budaya religius berjalan dengan lancar dan berkembang.

c. Tatanan Simbol Budaya

Peneliti mengamati bahwa dalam tatanan simbol yang ada di pondok pesantren Darul Musthofa, berdasarkan hasil observasi dapat klasifikasikan menjadi tiga macam yaitu:

1) Simbol-simbol budaya dalam bentuk atribut yang digunakan oleh santri di pondok pesantren Darul Musthofa yaitu berupa: (1) menggunakan jubah saat sekolah khusunya bagi murid baru yang MTs dan MA, (2) penggunaan cadar (purdah) bagi santriwati, (3) menggunakan busana muslim dan sarung (4) menggunakan peci bagi santriwan. Semua itu merupakan bentuk simbol-simbol khusus dalam bentuk atribut yang digunakan santri dan menjadi ciri khas pondok pesantren Darul Musthofa.

2) Menyelenggarakan aktivitas seni, salah satu strategi dalam mengembangkan budaya religius, karena santri akan termotivasi untuk menunjukkan bakat dan keahliannya, seperti seni musik yang diadakan di pondok pesantren Darul Muthofa yaitu Hadrah, kini menjadi sangat populer dikalangan masyarakat, dan dijadikan sebagai pengganti dari budaya tradisional masyarakat dalam acara khitanan, kurisan, dan pernikahan.

\section{KESIMPULAN}

TGH Syahri Ramdahan adalah sosok pemimpin teladan dan karismatik yang. Sumber keteladanan kepemimpinan TGH Syahri Ramadhan yaitu dari empat karakter utama yang ada pada Rasulullah SAW sebagai suri taudalan untuk seluruh umat islam, diantaranya: shiddiq, amanah, tabligh, dan fathonah. Sosok karismatik TGH Syahri Ramadhan muncul dari kepribadiannya yang shaleh, pengetahuan agama yang luas dan mendalam, sopan dan santun, tegas dan berani merupakan indikator yang menunjukkan bahwa TGH Syahri adalah orang yang berwibawa dan berkarisma. Wibawa dan karisma yang dimilikinya mampu mempengaruhi seluruh warga Pondok 
Pesantren dan menjadikannya sebagai figur yang dikagumi, disanjung, disegani, dihormati dan menjadi panutan bagi santri dan masyarakat.

Ketaatan warga pondok pesantren kepada TGH Syahri Ramdahan merupakan bentuk Otoritas karismatik yang timbul dari sosok TGH Syahri Ramadhan. Otoritas karismatik tersebut terbentuk dari wibawa dan karomahnya. Karisma TGH Syahri Ramadahan juga bersumber dari amalan-amalan atau wirid yang diamalkan, seperti; Hizib Nahdlatul Wathan, Thariqat Hizib Nahdlatul Wathan, dan Syawriqul Anwar, yang beliau sering amalkan bersama seluruh warga pondok pesantren. Ketaatan warga pondok pesantren terhadap otoritas karismatik TGH Syahri Ramadahan adalah kultur NW yang menjadi prinsip dasar ketaatan kepada pimpinan yaitu "sami'na watho'na" yang artinya kami mendengar kami setia.

Budaya religius dengan 5 dimensi keberagaman terbentuk melalui: (1) Dimensi keyakinan (religious belief) dengan penanaman nilai aqidah ahlussunah wal jamaah dengan mempercayai keberadaan rukun iman yang enam yaitu keyakinan pada Allah SWT, Malaikat, kitab Allah, Nabi dan Rasul, datangnya hari ahir, dan keyakinan pada qada dan qadar (ketentuan baik dan buruk). (2) dimensi praktik agama (Religious Practice) dengan melaksanakan ibadah wajib yang tercermin dala rukun Islam yang lima dan ibadah sunnah dengan melaksanakan perkara yang mendatangkan pahala dan kebaikan bagi dirinya. (3) dimensi pengalaman (religious feeling) kesadaran pribadi setiap santri bahwa segala perbuatan hanayalah bentuk ketaatan kepada Allah SWT, sehingga dilaksanakan dengan sungguh-sungguh. (4) Dimensi pengetahuan agama (religious knowledge) terbagi menjadi tiga pengetehuan yang ada dilingkungan pondok pesantren yaitu pengetahuan Iman dan Islam, Ibadah, da pengetahuan akhlak. (5) Dimensi konsekuensi (religious effect), merupakan implikasi dari keempat dimensi terbagi menjadi dua inti pokok yaitu aspek keimanan dan ibadah dengan melaksanakan seluruh rangkaian ritus-ritus keagamaan dengan harapan mendapatkan ridho Allah SWT untuk menggapai surga.

Budaya religius pada PP Darul Musthofa ada tiga macam, yaitu; (1) budaya religius disekolah berupa kegiatan-kegiatan keagamaan seperti berdo'a/wirid, ngaji, sholat, tadarus Al-Qur'an dan ihtiram. (2) budaya religius di Asrama dalam seperti sholat sunnah tasbih, acara PHBI, dan puasa sunnah. (3) budaya religius pada masyarakat dengan istighosah (doa' bersama) dan iringan hadrah dalam kegiatan adat dan budaya masayrakat sekitar seperti acar khitanan dan kurisan.

Strategi PP Darul Musthofa dalam pengembangan budaya religius untuk warga pesantren, yaitu: pertama: Tatanan Nilai yang Dianut, meliputi; idiologi ahlusunnah wal-jamaah yang bermazhab imam as-Syafii, yang tergolong pada tiga kriteria yaitu aqidah, syariah, dan tasawuf. Kedua: Praktik Keseharian, meliputi; 1) melaksanakan kegiatan rutin setiap hari yang meliputi ibadah, pendidikan dan akhlak 2) menjadikan kegiatan keagamaan sebagai kegiatan wajib dengan menetapkan aturan serta sanksi bagi yang melanggar aturan tersebut 3) menciptakan lingkungan pondok pesantren yang religius, berupa cara berpakaian yang serba islami dan harus berprilaku dengan baik dan sopan 4) melibatkan seluruh guru dan pengurus asrama sebagai contoh dan 
teladan bagi santri. Ketiga: menganut tatanan simbol yang meliputi; pengunaan atribut dan aktivitas seni.

\section{REFERENSI}

Alfian, M. A. (2009). Menjadi Pemimpin Politik: Perbincangan Kepemimpinan dan Kekuasaan (Cet. 2). Gramedia Pustaka Utama.

Arifin, Z. (2017). Authority of Spiritual Leadership at Pesantren Temboro Based on Jamaah Tabligh Ideology. Jurnal Pendidikan Islam, 6(2), 265-292. https://doi.org/10.14421/jpi.2017.62.265-292

Chotimah, C., \& Fathurrahman, M. (2014). Komplemen Manajemen Pendidikan Islam; Konsep Integratif Pelengkap Manajemen Pendidikan Islam. Teras.

Creswell, J. W., Lazuardi, A. L., \& Qudsy, S. Z. (2015). Penelitian kualitatif \& desain riset: Memilih diantara lima pendekatan (Ed. 3). Pustaka Pelajar.

Danim, S. (2010). Kepemimpinan pendidikan: Kepemimpinan jenius (IQ + EQ), etika, perilaku motivasional dan mitos. Alfabeta.

Dhofier, Z. (2011). Tradisi Pesantren Studi tentang Pandangan Hidup Kiai dan Visinya Mengenai Masa Depan Indonesia (9th ed.). LP3ES.

Fahrurrozi. (2010). Tuan Guru Dalam Idealitas Normatif Dengan Relialitas Sosial Pada Masyarakat Lombok. Jurnal Penelitian Keislaman, 7(1), 16.

Farhan, L. P., \& Hadisaputra, P. (2020). Tasawuf Pesantren: Jalan Menuju Revolusi Spiritual. Al-Fikr: Jurnal Pendidikan Islam, 6(2), 53-64. https://doi.org/10.32489/alfikr.v6i2.74

Fitriani, M. I. (2016). KEPEMIMPINAN KHARISMATIS-TRANSFORMATIF TUAN GURU DALAM PERUBAHAN SOSIAL MASYARAKAT SASAK-LOMBOK MELALUI PENDIDIKAN. 16(1), 22.

Hermino, A. (2014). Kepemimpinan Pendidikan Di Era Globalisasi (Cet. 1). Pustaka Pelajar.

Hidayat, A., \& Machali, I. (2012). Pengelolaan Pendidikan: Konsep, Prinsip, dan Aplikasi dalam Mengelola Sekolah dan Madrasah. Kaukaba.

Karim, A. G. (2009). THE PESANTREN-BASED RULING ELITE IN SUMENEP IN THE POSTNEW ORDER INDONESIA. JOURNAL OF INDONESIAN ISLAM, 3(1), 97-121. https://doi.org/10.15642/JIIS.2009.3.1.97-121

Kartono, K. (2001). Pemimpin dan kepemimpinan: Apakah pemimpin abnormal itu. Raja Grafindo Persada. 
Kurdi, S. (2007). Peranan Elit Ulama di Negeri Para Mullah ( Studi Pemikiran Khoemeini Tentang Wilayatul Faqih ). Jurnal Hermeneia|Vol-6-No-1-2007. https://digilib.uin-suka.ac.id/id/eprint/8518/

Mastuhu. (1994). Dinamika sistem pendidikan pesantren: Suatu kajian tentang unsur dan nilai sistem pendidikan pesantren. INIS.

Muhaimin. (2011). Pemikiran dan aktualisasi pengembangan pendidikan Islam (Cet. 1). Rajawali Pers.

Muhtarom H. M. (2005). Reproduksi ulama di era globalisasi: Resistansi tradisional Islam (Cet. 1). Pustaka Pelajar.

Nasip, A., Mahyuni, M., \& Nuriadi, N. (2019). Nilai Pendidikan, Sosial, Kultural, dan Spiritual dalam Wasiat Renungan Masa Karya Tgkh. Zainuddin Abdul Madjid: Tinjauan Hermeneutika. LINGUA : Jurnal Bahasa, Sastra, Dan Pengajarannya, 16(2), 271-284. https://doi.org/10.30957/lingua.v16i2.607

Nizar, S. (2013). Sejarah Sosial dan Dinamika Intelektual Pendidikan Islam di Nusantara. Kencana.

Nugroho, I. (2016). Kepemimpinan perpaduan iman, ilmu \& akhlak (Cet. 1). Pustaka Pelajar.

Putrawan, A. D. (2014). DEKARISMATISASI TUAN GURU DI PULAU LOMBOK NUSA TENGGARA BARAT. In Right; Jurnal Agama dan Hak Asasi Manusia, 5(2), 50.

Raharjo, D. (1995). Pesantren dan Pembaharuan (Cet. 5). LP3ES.

Ramayulis, R., \& Mulyadi, M. (2017). Manajemen dan kepemimpinan pendidikan islam (Cet. 1). Kalam Mulia.

Robertson, R. (1993). Agama :dalam Analisa dan Interpretasi Sosiologis (E. 1, Cet. 3). Raja Grafindo Persada.

Rohmaniyah, I., \& Woodward, M. (2012). Wahhabism, Identity, and Secular Ritual: Graduation at an Indonesian High School. Al-Jami'ah: Journal of Islamic Studies, 50(1), 119-145. https://doi.org/10.14421/ajis.2012.501.119-145

Steenbrink, K. A. (1986). Pesantren Madrasah Sekolah Pendidikan Islam dalam Kurun Modern. LP3ES.

Sugiyono. (2008). Metode penelitian pendidikan: (Pendekatan kuantitatif, kualitatif dan $R \& D)$. Alfabeta.

Sukamto. (1999). Kepemimpinan Kiai dalam Pesantren,. LP3ES.

Thohri, dkk, M. (2016). Barokah Cinta Maulana. IAIH NW Lombok Timur Press.

Thompson, H. M. (1977). Weber and Islam: A critical study by Bryan S. Turner London and Boston, Routledge \& Kegan Paul, 1974. Pp. ix+212. $£ 4.50$. The Journal of 
Evaluasi: Jurnal manajemen Pendidikan Islam

ISSN (P): 2580-3387, ISSN (E): 2615-2886

Vol. 5 No. 2 September 2021

Modern African Studies, 15(2), 342-343.

https://doi.org/10.1017/S0022278X00054069

Turner, B. S. (1974). Weber and Islam: A critical study. Routledge \& Kegan Paul.

Usman, H. (2008). Manajemen: Teori,praktik, dan riset pendidikan. Bumi Aksara.

Yulk, G. (1998). Kepemimpinan dalam Organisasi. Prenhallindo.

Ziadi, M. R. (2018). Tarekat Hizib Nahdlatul Wathan Dan Perannya Dalam Perpolitikan Di Lombok. Refleksi: Jurnal Filsafat Dan Pemikiran Islam, 18(2), 207-239. https://doi.org/10.14421/ref.2018.1802-05 